\title{
How Many Are REALLY Out There!?!? ${ }^{1}$
}

\author{
Charles Jacoby, Nanette Holland, and Debbi Berger ${ }^{2}$
}

\section{UF | FLORIDIDA IFAS Extension}

The Institute of Food and Agricultural Sciences (IFAS) is an Equal

Opportunity Institution authorized to provide research, educational information and other services only to individuals and institutions that function with nondiscrimination with respect to race, creed, color, religion, age, disability, sex, sexual orientation, marital status, national origin, political opinions or affiliations. For more information on obtaining other extension publications, contact your county Cooperative Extension service.

U.S. Department of Agriculture, Cooperative Extension Service, University of Florida, IFAS, Florida A. \& M. University Cooperative Extension Program, and Boards of County Commissioners Cooperating. Larry Arrington, Dean.

\section{Copyright Information}

This document is copyrighted by the University of Florida, Institute of Food and Agricultural Sciences (UF/IFAS) for the people of the State of Florida. UF/IFAS retains all rights under all conventions, but permits free reproduction by all agents and offices of the Cooperative Extension Service and the people of the State of Florida. Permission is granted to others to use these materials in part or in full for educational purposes, provided that full credit is given to the UF/IFAS, citing the publication, its source, and date of publication.

\footnotetext{
${ }^{1}$ This document is CIR1504, an Activity in an Invasive Species Curriculum (CIR1496), and it is reprinted by permission of the Tampa Bay Estuary Program and The Florida Aquarium. Original EDIS publication date: January, 2007. It was supported by the Tampa Bay Estuary Program, the Florida Aquarium, the Department of Fisheries and Aquatic Sciences of the University of Florida, and the National Sea Grant College Program of the National Oceanic and Atmospheric Administration (NOAA), U.S. Department of Commerce, under NOAA Grant No. NA 16RG-2195. Visit the EDIS Web Site at http://edis.ifas.ufl.edu.

${ }^{2}$ Charles Jacoby, Assistant Professor, Department of Fisheries and Aquatic Sciences, Cooperative Extension Service, Institute of Food and Agricultural Sciences, University of Florida, Gainesville, 32611; Nanette Holland, Public Outreach Coordinator, Tampa Bay Estuary Program, 100 8th Avenue S.E., MS I-1 / NEP, St. Petersburg, FL 33701; Debbi Berger, Vice President of Education, The Florida Aquarium, Inc., 701 Channelside Drive, Tampa, Florida, 33602.
} 
This page was intentionally left blank. 


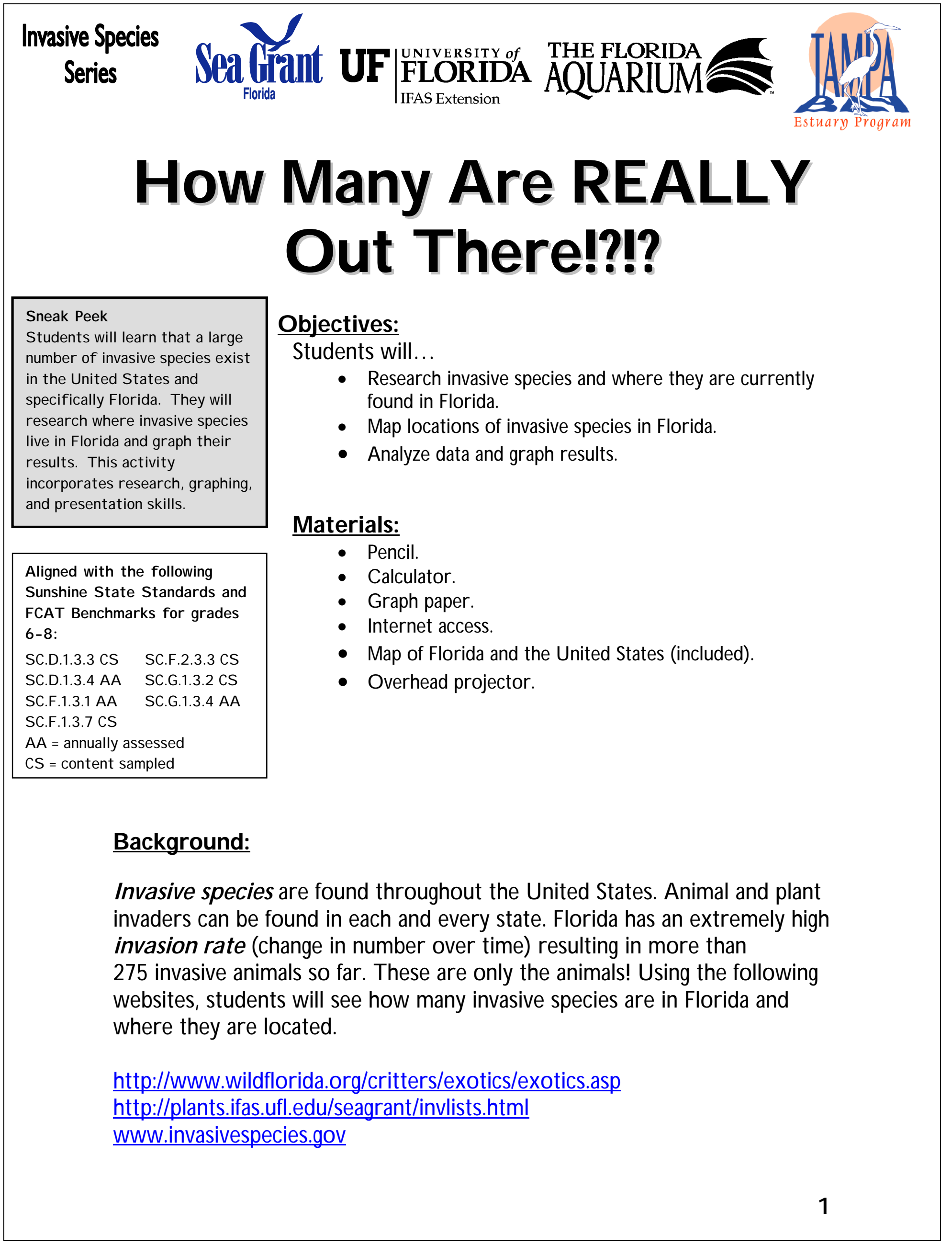




\section{Procedure:}

1. Copy U.S. map onto overhead transparency, using the one provided, or substituting one of your choosing.

2. Lead a discussion asking students what states have invasive species, citing common names of specific examples (see website list for sites that provide information on national invasive species). After soliciting answers, place the names of each invasive on the blank map of the United States on the overhead. All the states should be covered. Florida alone has more than 350 known invasive species (including plants).

3. Distribute the map of Florida and assign geographic regions (depending on class size) with several counties per group.

4. Groups should then research their counties in an attempt to name as many invasive species currently living in that area as possible.

5. Groups should now create a bar graph of the number of species in each county using the chart provided.

6. Have groups report on the invasive species they found in their geographic region, including how many are animals and how many are plants. 


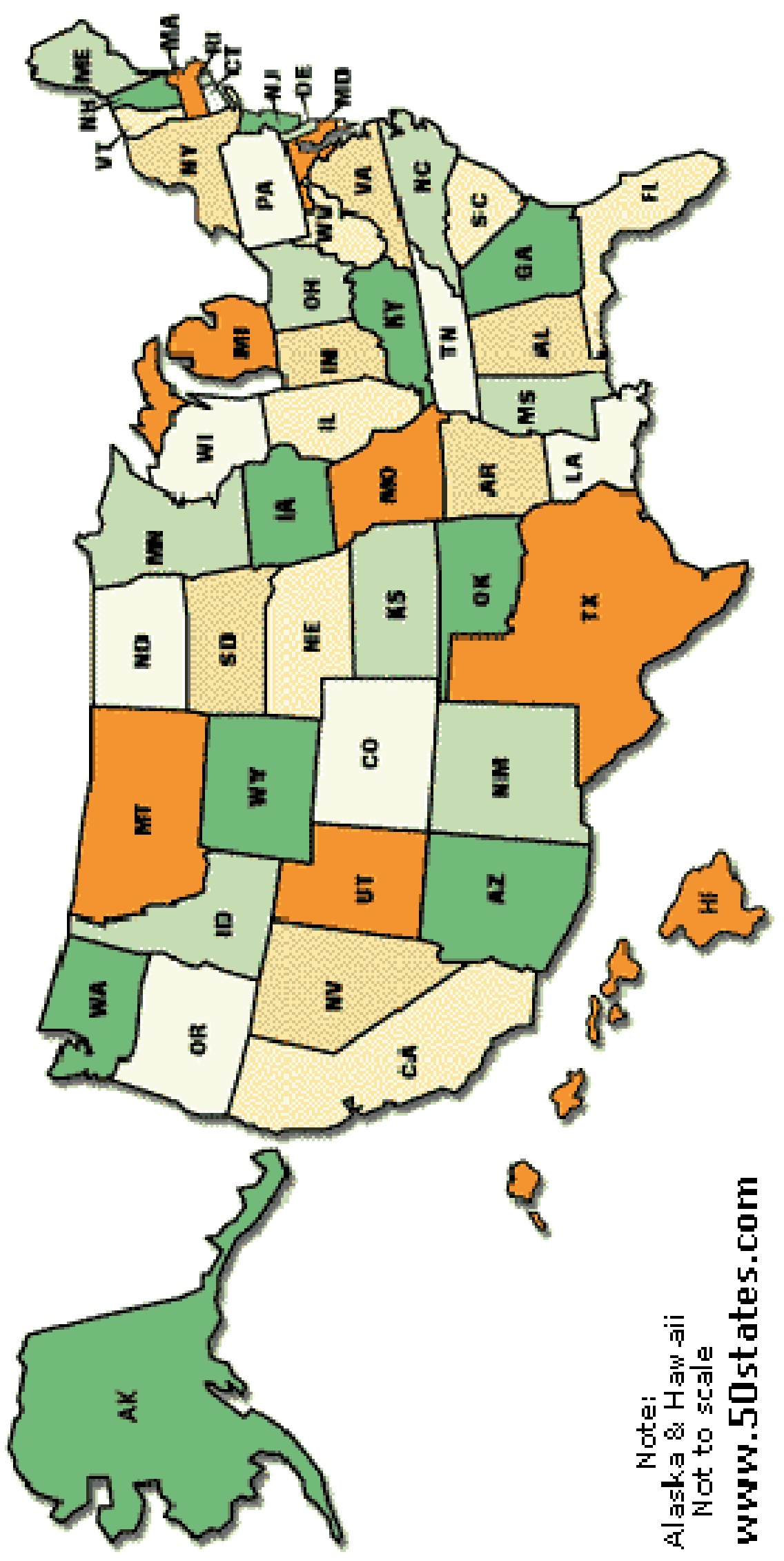




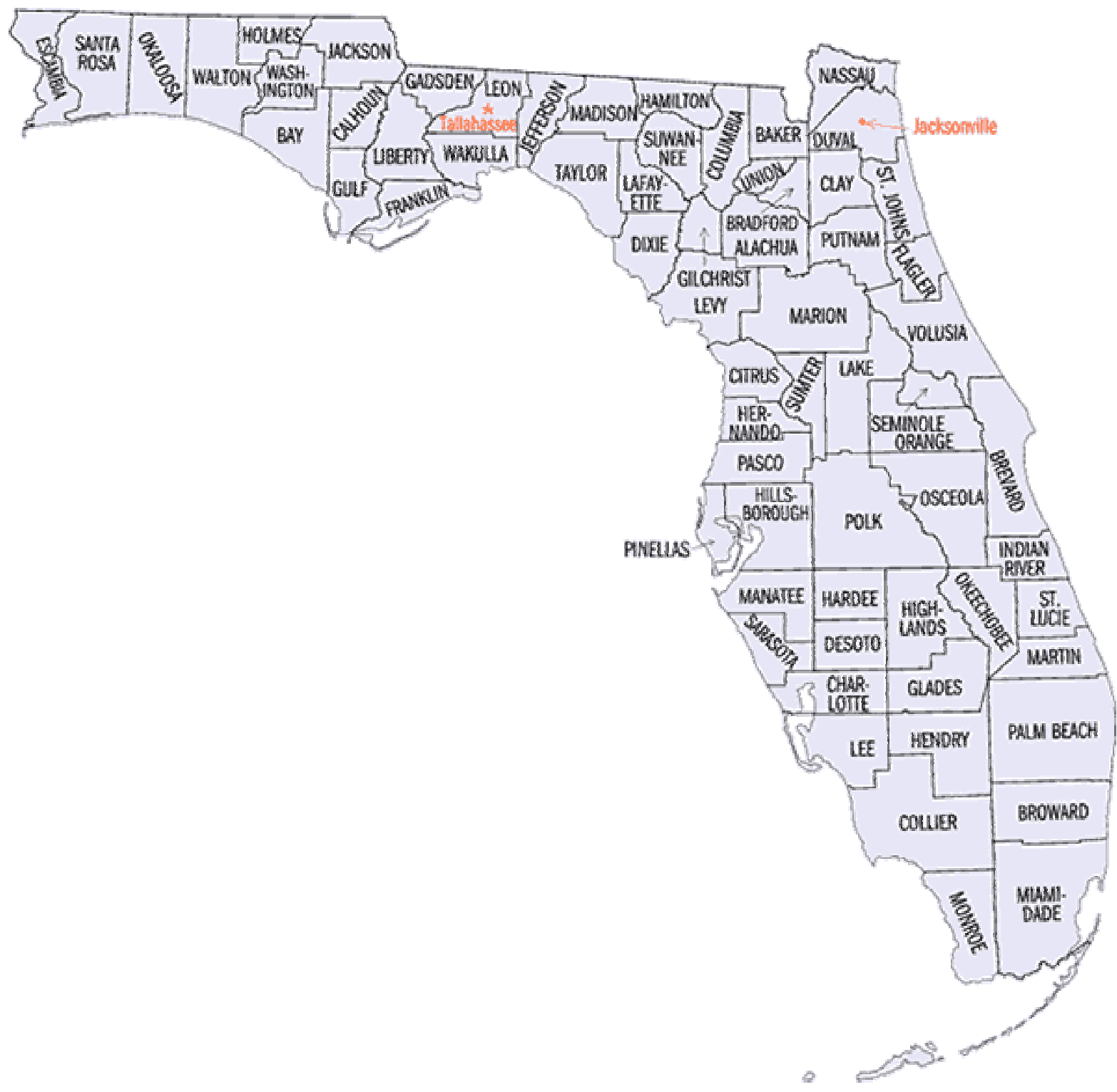

Map provided by digital-topo-maps.com at: http://county-map.digital-topo-maps.com/florida.shtml 


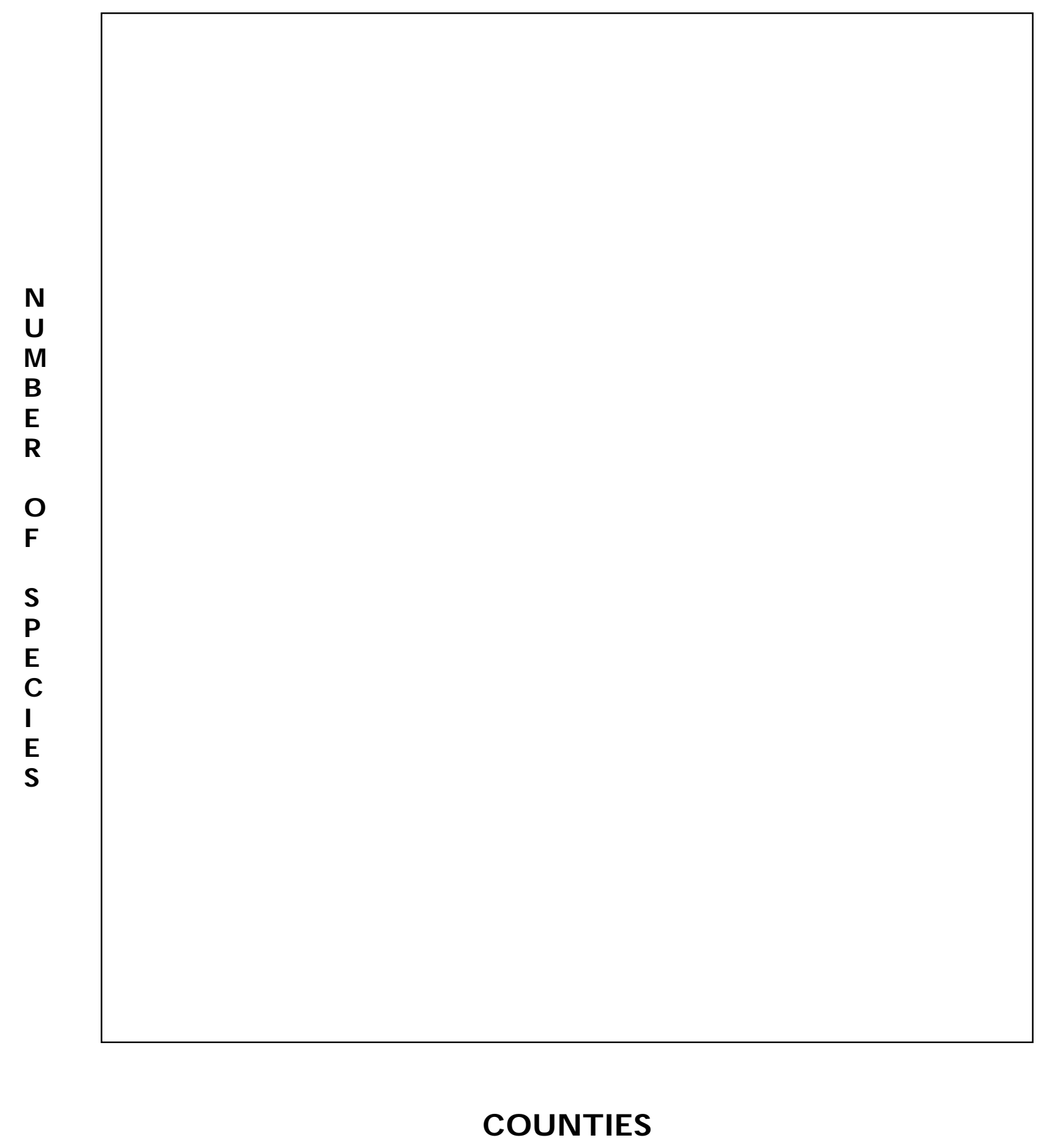




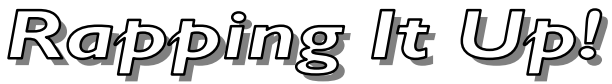

1. Before this activity, how many states did you think currently have invasive species living there? Do you think this number is increasing or decreasing and why?

2. Did you find more invasive plants or animals? Why do think this was the case?

3. W hich counties had the most invaders? W hy do you think this is? 


\section{Glossary:}

Invader/Invasive species - A plant or animal that is not native and causes harm, including disrupting natural ecosystems.

Invasion rate - How quickly invasive species are being established in a geographic region. A rate is a change in something over time. 